\title{
HUBUNGAN ANTARA KOORDINASI MATA TANGAN DAN AGILITY DENGAN KEMAMPUAN FLYING SHOOT PADA ATLET PUTRA KLUB BOLA TANGAN UNIVERSITAS NEGERI JAKARTA.
}

\author{
Aulia Putri Lestari ${ }^{1}$, Sujarwo ${ }^{2}$, Tirto Apriyanto ${ }^{2}$ \\ ${ }^{1}$ Program Studi Ilmu Keolahragaan \\ ${ }^{2}$ Fakultas Ilmu Keolahragaan Universitas Negeri Jakarta, Kampus B, Jakarta
}

\begin{abstract}
Abstrak. Penelitian ini bertujuan untuk mengetahui hubungan koordinasi mata tangan dengan kemampuan flying shoot, hubungan agility dengan kemampuan flying shoot, hubungan antara koordinasi mata tangan dan agility secara bersama-sama dengan kemampuan flying shoot. Penelitian ini menggunakan metode deskriptif dengan teknik studi korelasi. Sampel dalam penelitian ini adalah 20 orang dari jumlah populasi 50 orang atlet bola tangan Universitas Negeri Jakarta dengan menggunakan teknik purposive sampling, yaitu berdasarkan ciri-ciri atau karakteristik yang sudah diketahui sebelumnya berdasarkan gender (laki-laki), pengalaman (kejuaraan) minimal kejurnas, aktif latihan 3 kali seminggu dengan melihat absen kehadiran saat latihan. Instrumen penelitian menggunakan tes koordinasi mata tangan dengan alat eye-hand coordination trainer, tes agility menggunakan tes side step senor, dan tembakan flying shoot menggunakan alat gawang sasaran angka. Teknik pengujian hipotesis dilakukan dengan menggunakan teknik analisis statistika korelasi sederhana dan korelasi ganda yang dilanjutkan dengan uji-t pada taraf signifikasi $\alpha=0,05$. Berdasarkan dari hasil penelitian yang telah dilakukan, maka dapat ditemukan hasil penelitian menunjukkan: pertama, terdapat hubungan yang berarti antara koordinasi mata tangan dengan flying shoot, dengan persamaan garis linier $\hat{\mathrm{Y}}=10+0,30 \mathrm{X} 1$, koefisien korelasi (ry1) $=0,30$ dan koefisien determinasi $\left(\right.$ ryl$\left.^{2}\right)=0,2209$, yang berarti variabel koordinasi mata tangan memberikan sumbangan Dengan kemampuan flying shoot sebesar 22,1\%. Kedua, Terdapat hubungan yang berarti antara agility dengan kemampuan flying shoot, dengan persamaan garis linier $\hat{Y}=10+0,47 \mathrm{X} 2$., koefisien korelasi (ry2) $=0,47$ dan koefisien determinasi $\left(\mathrm{ry}^{2}\right)=0,2209$ yang berarti variabelagility memberikan sumbangan dengan kemampuan flying shoot sebesar 22,1\%. Ketiga, terdapat hubungan yang berarti antara koordinasi mata tangan dan agility dengan kemampuan flying shoot dengan persamaan garis linier $\hat{\mathrm{Y}}=10+$ $0,25 \mathrm{X}_{1}+0,22 \mathrm{X}_{2}$, koefisien korelasi Ry1-2 $=0,37$ dan koefisien determinasi $(\text { Ry1-2) })^{2}=0,14$ yang berarti variabel Koordinasi mata tangan dan agility memberikan sumbangan dengan kemampuan flying shootsebesar $14 \%$. Dalam penelitian ini koordinasi mata tangan dan agilitysecara bersama-sama memberikan kontribusi sebesar $14 \%$ pada kemampuan flying shoot. Untuk itu disarankan agar peneliti yang lain juga mencari faktor lain yang memberikan kontribusi yang baik dengan teknik kemampuan flying shoot.
\end{abstract}

Kata Kunci : Koordinasi Mata Tangan dan Agility, Flying Shoot, Bola Tangan. 


\section{PENDAHULUAN}

Olahraga adalah suatu kegiatan yang memiliki tujuan antara lain memperoleh kesehatan, kebugaran, kegembiraan serta dapat meningkatkan kesegaran jasmani. Dengan olahraga dapat membangun manusia Indonesia yang sehat jasmani dan rohani sehingga menghasilkan sumber daya manusia yang baik dan berkualitas. Olahraga juga bisa dijadikan sebagai alat pemersatu bangsa melalui pembinaan pada setiap cabang olahraga untuk diarahkan kearah peningkatan prestasi secara optimal.

Olahraga bolatangan merupakan salah satu permainan olahraga sama seperti halnya olahraga permainan sepak bola, bola basket, dan yang lainnya. Karena permainan ini mengandalkan power (gabungan antara kekuatan dan kecepatan) selain power kelincahan konsentrasi kesinambungan gerak juga diperlukan. Olahraga bolatangan juga merupakan salah satu olahraga permainan tua. Dilihat dari bentuk dasar permainannya yaitu melempar dan menangkap. Permainan bola tangan indoor (dengan 7 pemain) berkembang pesat dan bertambah populer, karena pola permainannya sangat menarik. Permainan berlangsung dengan tempo yang cepat, dinamis disertai taktik dan teknik yang spektakuler dari para pemain dan juga bolanya diakhiri dengan gerakan menembak yang dilakukan dengan cepat, keras, dan tepat. Bola tangan memperlihatkan keterampilan gerak yang tinggi gabungan dari lari, lompat dan melempar bola. Seorang pemain bola tangan harus memliki kemampuan tinggi dalam koordinasi, kelincahan, kecepatan dan daya tahan serta kekuatan. flying shoot adalah teknik menembak yang efektif untuk menciptakan gol ke gawang, Dalam cabang olahraga bola tangan melempar adalah hal utama yang harus dikuasai oleh setiap pemain bola tangan dan merupakan keterampilan dasar yang harus ada pada olahraga bola tangan, karena dalam olahraga bola tangan melempar berfungsi sebagai usaha untuk melakukan operan dan berfungsi sebagai tembakan atau lemparan ke arah gawang. Pendapat ini diperkuat dengan adanya pendapat dari Agus Mahendra bahwa salah satu karakteristik gerak dasar yang dominan dalam bola tangan adalah melempar, yang merupakan keterampilan nonlokomotor.

Koordinasi mata tangan dan agility sangat berguna dalam melakukan tembakan flying shoot ke gawang karena cara atau teknik menembak pada olahraga bola tangan ini sangat efektif dibanding dengan cara atau teknik-teknik menembak yang lain yang ada pada olahraga bola tangan dalam mencetak gol serta sangat sering mendapatkan peluang karena flying shoot atau tembakan saat melayang diudara ini jarak menembak dengan gawang semakin dekat dan sulit untuk ditebak arah tembakannya. Flying shoot mempunyai kelebihan dibanding dengan cara menembak yang lainnya, selain jarak tembak semakin memendek serta efektif, flying shoot juga sangat sering digunakan ketika ada peluang sekecil mungkin karena ketika melayang diudara dan melebihi garis gawang tetapi masih dalam keadaan melayang dan bola terbang wasit tidak akan membunyikan peluit tanda line, itu yang sangat menguntungkan bagi pemain oleh karena itu mayoritas pemain bola tangan sangat menyukai dan menguasai cara flying shoot ini. Segala sesuatu pasti ada kelebihan dan kekurangan begitu juga dengan flyingshoot kekurangan flying shoot adalah apabila atlet kurang menguasai teknik ini pasti akan sering mendapatkan pelanggaran karena bola tangan tidak boleh melewati garis gawang selain itu juga ketika melakukan flyingshoot saat ingin melayang sering kali dicederai oleh lawan.

\section{Tinjauan Pustaka}

\section{Hakikat Bola Tangan}

Bola tangan adalah olahraga permainan beregu yang menggunakan bola sebagai alat, yang dimainkan dengan menggunakan satu atau kedua tangan. Bola tersebut boleh dilemparkan, atau 
ditembakkan, permainan ini adalah memasukan bola sebanyak-banyaknya kedalam gawang lawan, dan mencegah agar tim lawan tidak dapat memasukkan bola kegawang sendiri. Dalam permainan ini lebih tepat disebut sebagai permainan kombinasi antara permainan basket dan permainan sepak bola, karena keterampilan teknik dasar ketika memainkan bola dengan tangan lebih menyerupai teknik dasar basket yang terdiri dari passing, dribling, shooting.Sedangkan lapangan permainan serta bentuk-bentuknya lebih mirip lapangan sepak bola, terdiri dari gawang berjaring, serta daerah - daerah yang dibatasi oleh peraturan yang membatasi peluang gerak pemain,termasuk mekanisme permainannya.

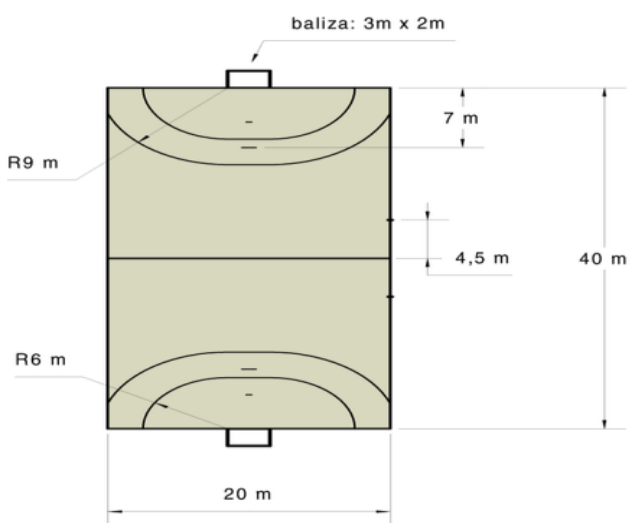

Gambar 2.1. Lapangan Bola Tangan

Sumber:http://antonborneojach.wordpress.com/200 9/02/23/lapangan-dan-fasilitas-bola-tangan.

\section{Hakikat Flying Shoot}

Dalam olahraga bola tangan shooting salah satu serangan yang sangat penting dan bagaimana sebanyak mungkin kita mencetak gol ke gawang lawan, pemain penyerang diperkenankan melakukan berbagai macam cara menembak, Sesuai dengan kemahirannya dan tentu saja sesuai dengan situasi permainan pada saat tersebut.

Dalam garis besarnya, cara-cara menembak bola adalah sebagai berikut :
1. The standing throw shoot (menembak dalam sikap berdiri)

2. The jump shoot (menembak pada saat melompat keatas)

3. The dive shoot (menembak pada saat melompat kedepan)

4. Thefall shoot(menembak sambil menjatuhkan

diri kesamping/kedepan)

5. The side shoot (menembak dari samping badan)

6. The flying shoot (menembak pada saat melayang)

7. The reverse shot (tembakan membalik/memutar).

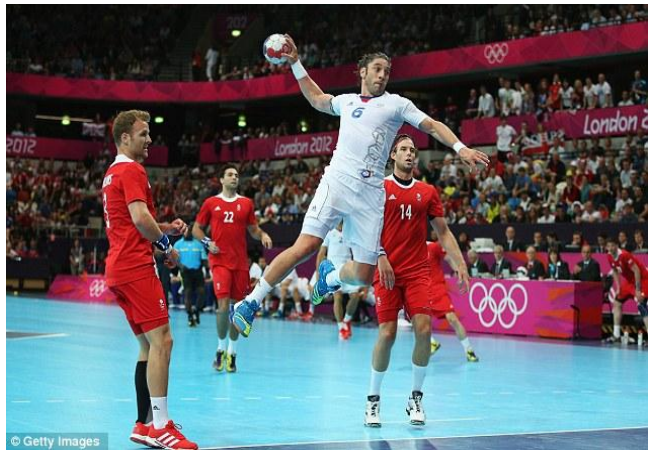

Gambar 2.2. Tembakan Melayang (flying shoot) Sumber:http://i.dailymail.co.uk/i/pix/2012/07/29/ar ticle-0-14482F68000005DC-890_634x412.jpg.

Tahapan teknik untuk menembak melayang dalam progresi berikut:

1. Menghampiri, menjadi salah satu gerakan untuk menerima bola. Pemain yang ingin melakukan tembakan melayang pergerakan menghampiri berati mengatur jarak dengan pemain bertahan dan garis batas menembak/garis 6 meter. Pastikan Anda siap untuk bergerak maju ketika anda mendapatkan bola. Setelah menerima operan, berlari tiga langkah kedepan untuk mempercepat laju menuju garis 6 meter. Semakin besar kecepatan anda, semakin besar power yang yang dihasilkan untuk bisa menembus pertahanan ketika melompat ke daerah tujuan. 


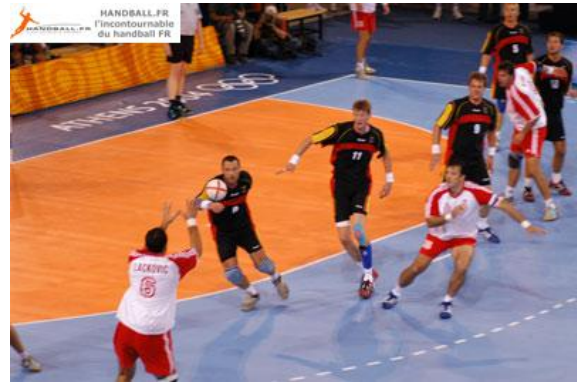

Gambar 2.3. Menghampiri Bola Saat Dipassing Sumber:http://www.google.co.id/search?q=handbal $\underline{1 \& o e=u t f-8 \& r l s=\text { org. }}$.

2. Penempatan, mengusahakan langkah terakhir sedekat mungkin dengan garis 6 meter batas menembak dengan sudut 45 derajat dalam melakukan lompatan, agar memperpendek jarak lemparan dengan tujuan gawang.

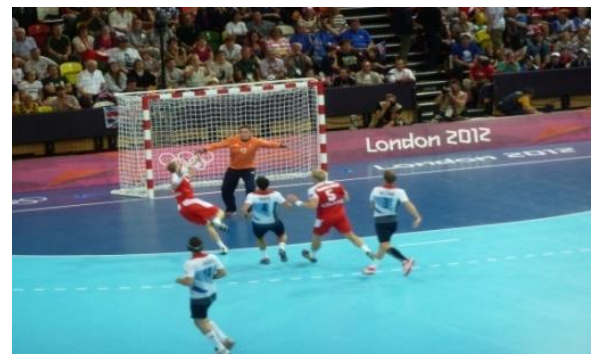

Gambar 2.4. Penempatan Diri untuk Melakukan Shooting

Sumber:http://icelanddefrosted.files.wordpress.com /2012/09/istakeshot.jpg

3. Melompat dan melayang, pemain harus dapat mengonsentrasikan diri untuk melompat cukup jauh ke depan dan cukup tinggi, dan kemudian mempertahankan sikap melayang selama mungkin. Ketinggian yang cukup saat melayang sangat mempengaruhi tingkat keberhasilan tembakan tersebut.

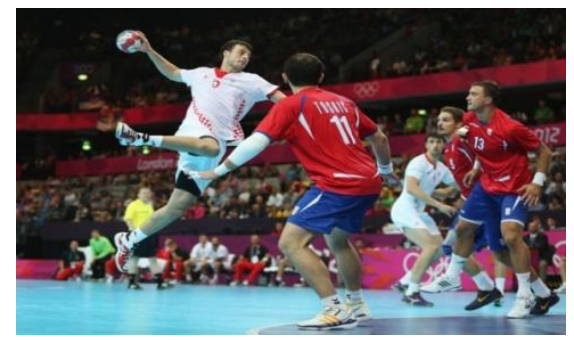

Gambar 2.5. Melompat untuk Melakukan dan Melepaskan Bola

Sumber:http://www2.pictures.zimbio.com/gi/Olym pics+Day+4+Handball+_KuF4eKe8XDl.jpg
4. Tembakan, ketika anda berada diudara di atasdaerah tujuan, lepaskan tanganyang mendukung dan angkat bola sampai ke posis imelempar. Fokus pada gawang dan tahan posisi ini sampai anda siap untuk menembak. Kemudian memutar bahu anda untuk menghadap gawang, bantu dengan siku anda, tarik lengan anda dan tekan pergelangan tangan anda. Gerakan lanjutan dengan membiarkan momentum tubuh Anda untuk terus maju dan gerakan lengan anda menyilang pada tubuh anda setelah melempar. Dan diakhiri dengan mendarat pada kaki anda yang melompat.

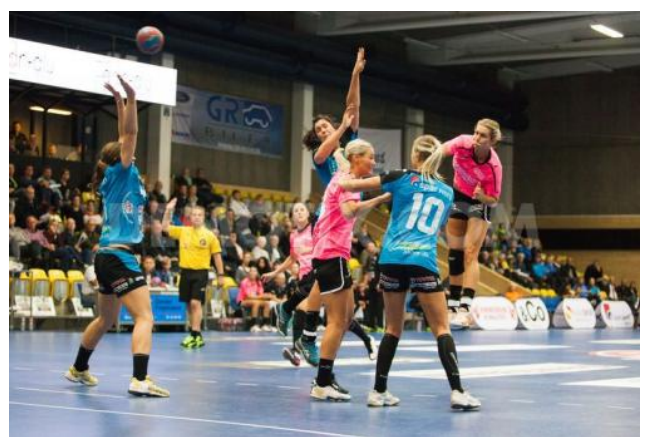

Gambar 2.6. Tembakan Ke Gawang Sumber:http://static3.demotix.com/sites/default/file s/imagecache/a_scale_large/28008/photos/1380796 934-skive-fh-loses-3037-to-randers-hk-in-danishwomens-handball_2850778.jpg

\section{Hakikat Koordinasi Mata Tangan}

Olahraga bola tangan merupakan olahraga yang melibatkan semua anggota tubuh dan membutuhkan komponen fisik untuk dapat melakukan gerakan secara efisien dan efektif. Salah satu komponen fisik yang dibutuhkan adalah koordinasi. M. Sajoto berpendapat bahwa : koordinasi adalah kemampuan seseorang untuk mengintegrasikan bermacam - macam gerakan yang berbeda kedalam pada gerakan tunggal secara efektif.

Menurut Don R. Kirkendal dkk koordinasi adalah keseluruhan dari pola gerak otot pada saat melakukan penampilan gerak yang pada akhirnya menghasilkan tingkat ketertampilan 
seseorang. Koordinasi sebagai suatu kemampuan interaksi kerja sistem syaraf pusat dan sistem otot penggerak dalam implementasi suatu gerakan tunggal yang melibatkan beberapa komponen otot dan organ koordinasi menjadi istimewa, karena terjadi sebagai gerakan dengan tingkat keterampilan tinggi pada cabang-cabang olahraga. Untuk mempertahankan kecepatan gerak membutuhkan komponen biomotor dasar yang baik. Seperti yang dikemukakan Bompa, koordinasi merupakan kemampuan biomotorik yang kompleks dan memiliki hubungan yang erat dengan kecepatan, kekuatan, daya tahan, dan kelentukan.

Dari pendapat diatas koordinasi dapat diklasifikasikan sebagai berikut:

a. Koordinasi umum mengatur kapasitas seseorang dalam melaksanakan berbagai macam keterampilan motorik secara rasional serta terlepas dari spesialisasi cabang olahraganya.

b. Koordinasi khusus mencerminkan kemampuan seseorang dalam melakukan berbagai macam gerakan cabang olahraga tertentu dengan sangat cepat tetapi mudah, lancar dan tepat.

Koordinasi umum menggambarkan keterampilan sederhana yang menampilkan kecakapan gerak, perpaduan antara gerakan lengan dan tungkai, seperti kemampuan berlari, melompat, melempar dengan efisien. Sedangkan koordinasi khusus merupakan keterampilan yang lebih kompleks berupa rangkaian gerak dengan tingkat kesulitan tertentu, sehingga membutuhkan kecakapan khusus untuk menampilkan gerakan suatu cabang olahraga dengan mulus, tepat dan cepat. Berdasarkan pada dua klasifikasi diatas maka faktor-faktor yang sangat mendukung dalam koordinasi adalah :

a. Kemampuan berpikir atau itelegensi olahraga yang memiliki oleh atlet.

b. Kehalusan dan ketepatan organorgan sensorik, khususnya analisator dan kinestetik (sensor gerak) sebagaimana pada keseimbangan dan irama kontraksi otot juga menunjukan faktor yang paling penting.

c. Pengalam motorik digambarkan melalui keterampialn tinggi yang beraneka ragam, membentuk faktor yang menentukan dalam kemampuan koordinasi seseorang atau kemampuan untuk belajar dengan cepat.

d. Tingkat pengembangan kemampuan biomotorik lainnya.

Jadi meningkatkan kemampuan koordinasi, dibutuhkan peningkatkan kemampuan berpikir dan intelegensi dalam menganalisis setiap gerakan sehingga menghasilakn kehalusan dan ketepatan gerak. Pengalaman motorik yang tinggi dan pengembangankomponen biomotor dari proses pelatihan juga menentukan keberhasilan dalam melakukan koordinasi.

Kordinasi mata tangan adalah gerakan yang terjadi dan informasi yang terintegrasi kedalam gerakan anggota badan. Pada dasarnya koordinasi merupakan kemampuan untuk mengontrol gerak tubuh, individu yang mempunyai koordinasi geraknya baik akan mampu mengendalikan gerak tubuhnya sesuai dengan kemampuannya, sehingga mampu menghasilkan suatu bentuk keterampilan yang cukup sempurna. Kordinasi mata tangan kemampuan keterampilan yang tidak dapat diabaikan dan perlu dimiliki oleh atlet bola tangan didalam mempelajari gerakan dasar. Seperti pada keterampilan menembak ke gawang (shooting) hal ini dikarenakan penguasaan teknik gerakan perlu didukung oleh unsur-unsur kondisi fisik seperti koordinasi, kelincahan, daya ledak, dan kecepatan. Sehingga dapat disimpulkan koordinasi mata tangan merupakan kemampuan yang dapat meningkatkan keterampilan gerak termasuk pada menembak ke gawang (shooting). 


\section{Hakikat Kelincahan (Agility)}

Untuk menjadi pemain bola tangan yang handal, seorang pemain perlu memusatkan pikiran untuk membuat suatu keputusan dengan cepat dan tepat, keputusan yang cepat dan efisien sangat dibutuhkan karena di bola tangan kesempatan atau celah sekecil apapun harus dilihat dan dimanfaatkan dengan sebaik mungkin, kelincahan sangat dibutuhkan untuk mengelabuhi lawan agar ada daerah depan gawang untuk shooting. M.Sajoto menyatakan bahwa:"Kelincahan adalah kemampuan seseorang untuk merubah posisi di arena tertentu,seseorang yang mampu merubah suatu posisi yang berbeda kecepatan tinggi dengan koordinasi yang baik berarti kelincahan cukup baik". Menurut Johansyah Lubis:"Agility atau kelincahan adalah seperangkat keterampilan kompleks yang dilakukan oleh seseorang untuk merespons stimulus eksternal dengan perlambatan, perubahan arah, dan reacceleration,kelincahan dipengaruhi oleh persepsi atlet dan pengambilan kemampuan mengambil keputusan untuk dengan cepat mengubah arah". "Kelincahan adalah kemampuan untukmengubah arah atau posisi tubuh dengan cepat yang dilakukan bersamasama dengan gerakan lainnya.

\section{Hakikat Bola Tangan FIK UNJ}

Fakultas Ilmu Keolahragaan Universitas Negeri Jakarta adalah Universitas Negeri yang mempelopori bola tangan di Indonesia. Kejuaraan bola tangan diadakan di Bali pada tahun 2008. 80\% pemain Indonesia kejuaraan tersebut adalah mahasiswa Fakultas Ilmu KeolahragaanUniversitas Negeri Jakarta. Sejak saat itu FIK UNJ menjadi tempat dilahirkannya atlet-atlet dan tempat dikembangkannya olahraga bola tangan serta dibentuknya klub bola tangan yang diketuai oleh M. Arif dan Mustafa Mansyur sebagai pembina.

Klub bola tangan FIK UNJ memenangkan kejuaraan antar mahasiswa di Jakarta sebagai juara pertama putra dan putri pada tahun 2009. Kemudian, kembali meraih juara pertama putra putri di kejuaraan antar mahasiswa di Bandung pada tahun 2010. Serta meraih juara kedua kejuaraan bola tangan di Universitas Negeri Jakarta pada Juli 2011. Kejuaraan ketiga tersebut sangat meriah karena telah dipersiapkan sejak lama. Peserta yang mengikuti adalah mahasiswa mahasiswi dan pelajar putra putri sekolah menengah atas. Tuan rumah FIK UNJ menurunkan putra sebanyak 3 tim dan putri 3 tim. Masing-masing tim FIK kurang lebih sepuluh orang.

Dilihat dari tingkat prestasi, klub bolatangan FIK UNJ mengalami penurunan yang tentunya disebabkan oleh banyak faktor yang mempengaruhi. Di sisi lain peserta cabang olahraga bola tangan FIK UNJ hanya berjumlah sekitar 35 orang. Jika dibandingkan dengan jumlah keseluruhan mahasiswa FIK UNJ, perkembangan olahraga bola tangan masih terlihat sangat lambat. Tingkat perkembangan olahraga bola tangan khususnya di FIK UNJ, tempat dilahirkannya atlet-atlet dan tempat dikembangkannya olahraga bola tangan serta dibentuknya klub bola tangan. Hasil dari penemuan hal-hal yang mempengaruhi lambatnya perkembangan bola tangan akan menjadi bahan untuk kemajuan perkembangan olahraga bola tangan.

\section{Kerangka Berpikir}

\section{Hubungan Koordinasi Mata Tangan dengan Flying Shoot}

Individu yang mempunyai

koordinasi geraknya baik akan mampu mengendalikan gerak tubuhnya sesuai dengan kemampuannya. Sehingga mampu menghasilkan suatu bentuk keterampilan yang cukup sempurna, seseorang dikatakan koordinasinya baik apabila ia mampu bergerak dengan mudah dan lancar dalam merangkaikan atau memadukan gerakan dengan baik, maka ia mampu melakukan aktifitas gerak dengan baik, 
Selain itu juga koordinasi merupakan faktor yang menentukan tidak hanya dapat memperoleh dan menyempurnakan teknik saja, melainkan penerapan dalam kondisi yang masih asing.

Teknik tembakan flying shoot dalam olahraga bola tangan adalah salah satu teknik atau cara tembakan yang sangat memerlukan koordinasi mata tangan yang bagus karena ketika atlet melakukan teknik tembakan ini saat posisi melayang atlet harus melihat sudut yang paling jauh yang tidak dapat dijangkau oleh kiper agar ketika ada kesempatan sekecil apapun akan maksimal dan efisien untuk menciptakan gol, bukan ketika menembak saja, koordinasi mata tangan ini sangat mendukung ketika posisi menyerang karena harus saling passing jarak jauh maupun dekat. Dengan demikian maka, koordinasi mata tangan adalah kemampuan keterampilan yang tidak dapat diabaikan dan perlu dimiliki oleh atlet bola tangan didalam memiliki gerakan dasar. Berdasarkan uraian diatas, maka dapat disimpulkan bahwa terdapat hubungan antara koordiansi mata tangan terhadap kemampuan flying shoot.

\section{Hubungan Agility dengan Flying Shoot}

Selain koordinasi mata tangan ada komponen kemampuan fisik lainnya yang menunjang kemampuan melakukan flying shoot yaitu agility, bukan di olahraga bola tangan saja yang memerlukan aglity bahkan disemua cabang olahraga sangat membutuhkan agility. Kelincahan (agility) adalah kemampuan untuk mengubah arah atau posisi tubuh dengan cepat yang dilakukan bersama-sama dengan gerakan lainnya. Kelincahan memiliki peran yang penting demi tercapainya kemampuan penampilan secara baik, seorang atlet sangat perlu untuk memiliki, memelihara, dan menjaganya agar kemampuan agility tetap menjadi satu kesatuan dengan kemampuan fisik yang lainnya. Apabila agility ini berkurang maka akan mempengaruhi kepada segala gerak yang akan dilakukan, bahkan gerakan dasarpun akan berantakan. Maka dari itu agilitysangatlah penting dalam memberi kontribusi untuk melakukan semua gerakan dalam cabang olahraga, di bola tangan agility berperan sangat penting karena agility ini membantu terciptanya peluang menciptakan gol, apabila seorang atlet tidak memiliki agility yang baik maka akan mempengaruhi gerakan saat akan melakukan flying shoot. Oleh karena itu seorang atlet bola tangan harus memiliki tingkat agility yang tinggi agar dapat melakukan flying shoot dalam kesempatan atau waktu sekecil apapun untuk menunjang banyak terciptanya gol karena pada prinsipnya permainan bola tangan itu cepat dan efektif. Berdasarkan uraian diatas, maka dapat disimpulkan bahwa terdapat hubungan antara agility terhadap kemampuan flying shoot.

\section{Hubungan AntaraKoordinasi Mata Tangandan Agility dengan Kemampuan Flying Shoot}

Kelincahan (agility) adalah kemampuan untuk mengubah arah atau posisi tubuh dengan cepat yang dilakukan bersama-sama dengan gerakan lainnya, Kelincahan memiliki peran yang penting demi tercapainya kemampuan penampilan secara baik. Sedangkan koordinasi merupakan suatu kemampuan untuk mengontrol gerak tubuh, seorang atlet bola tangan ia harus memiliki agility yang maksimal karena hal ini diperlukan ketika akan melakukan awalan tembakan flying shoot dengan kesempatan yang sangat kecil didepan gawang dengan cepat tanpa harus kehilangan keseimbangan serta kontrol terhadap bola.

Koordinasi merupakan kemampuan untuk mengontrol gerak tubuh individu yang mempunyai koordinasi yang geraknya baik akan mampu mengendalikan gerak tubuhnya sesuai dengan kemampuannya sehingga mampu menghasilkan suatu bentuk keterampilan yang baik. Penampilan gerakan yang diperlihatkan atlet bola tangan 
membutuhkan kemampuan koordinasi yang baik agar gerakan yang dihasilkan sangat efisien dan optimal.

Dengan demikian maka, koordinasi mata tangan adalah kemampuan keterampilan yang tidak dapat diabaikan dan perlu dimiliki oleh atlet bola tangan didalam mempelajari gerakan dasar. Seperti pada keterampilan menembak teknik flying shoot sangat membutuhkan penguasaan teknik gerakan perlu didukung oleh unsur-unsur kondisi fisik seperti koordinasi dan agility yang baik.

Dengan demikian kedua unsur kondisi fisik yaitu koordinasi dan kelincahan (agility) harus diperhatikan dalam meningkatkan kemampuan teknik menembak flying shoot dalam olahraga bola tangan, karena menjadi faktor keberhasilan menciptakan gol dalam pertandingan dan dapat meningkatkan prestasi yang lebih baik. Berdasarkan uraian diatas, maka dapat disimpulkan bahwa terdapat hubungan antara koordinasi mata tangan dengan agility terhadap kemampuan flying shoot.

\section{METODE}

Penelitian ini dilakukan dengan menggunakan metode deskriptif, yaitu statistik yang berfungsi untuk mendiskripsikan obyek yang diteliti melalui data sampel atau populasi. Dengan menggunakan teknik studi korelasi. Sampel dalam penelitian ini yaitu 20 orang mahasiswa dari 50 mahasiswa anggota klub bola tangan diambil dengan menggunakan teknik purposive sampling

Instrumen Penelitian. Instrumen penelitian yang digunakan untuk mengambil data dalam penelitian ini adalah: Tes koordinasi mata tangan menggunakan alat ukur Eye-Hand Coordination Traine, Tes agility menggunakan alat ukur Side Step Senor, Tes Hasil Tembakan Flying Shoot.

\section{HASIL DAN PEMBAHASAN}

Deskripsi Data. Deskripsi data berikut ini merupakangambaran tentang penyebaran data yang meliputi nilai terendah, nilai tertinggi, rata-rata, simpangan baku, median, modus, distribusi frekuensi, varians, serta histogram dari masingmasing variabel $\mathrm{X}_{1}, \mathrm{X}_{2}$ dan $\mathrm{Y}$.

\begin{tabular}{c|c|c|c} 
Variabel & $\begin{array}{c}\text { Koordinasi } \\
\text { mata } \\
\text { tangan } \\
\left(\mathbf{X}_{\mathbf{1}}\right)\end{array}$ & $\begin{array}{c}\text { Agility } \\
(\mathbf{X} 2)\end{array}$ & $\begin{array}{c}\text { Flying } \\
\text { shoot } \\
(\mathbf{Y})\end{array}$ \\
\hline $\begin{array}{c}\text { Nilai } \\
\text { terendah }\end{array}$ & 12,58 & 23 & 10 \\
\hline $\begin{array}{c}\text { Nilai } \\
\text { tertinggi }\end{array}$ & 16,58 & 40 & 18 \\
\hline Rata-rata & 14,05 & 31,75 & 12,90 \\
\hline Median & 14,58 & 31,5 & 14 \\
\hline $\begin{array}{c}\text { Simpang } \\
\text { an baku }\end{array}$ & 1,13 & 4,34 & 2,18 \\
\hline Varians & 1,28 & 18,83 & 4,77
\end{tabular}

Tabel 4.1. Deskripsi Data Penelitian

1. Variabel Koordinasi mata tangan $\left(\mathrm{X}_{1}\right)$ Hasil penelitian menunjukkan rentang skor koordinasi mata tangan $\left(\mathrm{X}_{1}\right)$ adalah antara 12,58 sampai dengan 16,58 , nilai rata-rata sebesar 14,05 simpangan baku sebesar 1,13 median 14,58. Distribusi Frekuensi dapat dilihat pada tabel 2 di bawah ini :

Tabel 4.2. Distribusi Frekuensi Koordinasi Mata Tangan $\left(\mathrm{X}_{1}\right)$

\begin{tabular}{c|c|c|c|c}
\multirow{2}{*}{ No } & \multirow{2}{*}{$\begin{array}{c}\text { Interval } \\
\text { Kelas }\end{array}$} & \multicolumn{2}{|c|}{ Frekuensi } & \multirow{2}{*}{ Titik } \\
\cline { 3 - 4 } & Absolut & $\begin{array}{c}\text { Relatif } \\
(\boldsymbol{\%})\end{array}$ & \\
\hline 1 & $12.58-13.18$ & 6 & $30 \%$ & 12.88 \\
\hline 2 & $13.19-13.79$ & 3 & $15 \%$ & 13.49 \\
\hline 3 & $13.80-14.40$ & 5 & $25 \%$ & 14.10 \\
\hline 4 & $14.41-15.01$ & 1 & $5 \%$ & 14.71 \\
\hline 5 & $15.02-16.58$ & 5 & $25 \%$ & 15.80 \\
\hline & Jumlah & 20 & $100 \%$ &
\end{tabular}

Berdasarkan data dari tabel 2 di atas dibandingkan dengan nilai rata-rata, terlihat testee yang berada pada kelas ratarata sebanyak 5 testee (25\%) dan yang berada di bawah kelas rata-rata sebanyak 3 testee (15\%), sedangkan testee yang berada di atas kelas rata-rata sebanyak 1 testee $(5 \%)$. 
2. Variabel Agility $\left(\mathrm{X}_{2}\right)$

Hasil penelitian menunjukkan agility $\left(\mathrm{X}_{2}\right)$ adalah antara 23 sampai dengan 40, nilai rata-rata sebesar 31,75 simpangan baku sebesar 4,34 median 31,5. Distribusi Frekuensi dapat dilihat pada tabel 3 di bawah ini:

\section{Tabel 4.3. Distribusi Frekuensi Agility}

\begin{tabular}{c|c|c|c|c}
\multirow{2}{*}{ No } & \multirow{2}{*}{$\begin{array}{c}\text { Interval } \\
\text { Kelas }\end{array}$} & \multicolumn{2}{c}{$\begin{array}{c}\mathbf{X}^{\mathbf{2}} \mathbf{2} \\
\text { Frekuensi }\end{array}$} & \multirow{2}{*}{ Titik } \\
\cline { 3 - 4 } & & Absolut & $\begin{array}{c}\text { Relatif } \\
\mathbf{( \% )}\end{array}$ & \\
\hline 1 & $23-26,4$ & 2 & $10 \%$ & 24,7 \\
\hline 2 & $26,5-30,9$ & 5 & $25 \%$ & 28,7 \\
\hline 3 & $31-33,4$ & 5 & $25 \%$ & 32,2 \\
\hline 4 & $33,5-36,9$ & 5 & $25 \%$ & 35,2 \\
\hline 5 & $37-40$ & 3 & $15 \%$ & 38,5 \\
\hline & Jumlah & 20 & $100 \%$ &
\end{tabular}

Berdasarkan tabel 3 di atas dibandingkan dengan nilai rata-rata, terlihat testee yang berada pada kelas ratarata sebanyak 5 testee (25\%) dan yang berada di bawah kelas rata-rata sebanyak 2 testee (10\%), sedangkan testee yang berada di atas kelas rata-rata sebanyak 3 testee $(15 \%)$.

\section{Variabel flying shoot (Y)}

Hasil penelitian menunjukkan rentang skor flying shoot $(\mathrm{Y})$ adalah antara 10 sampai dengan 18 , nilai rata-rata sebesar 12,90simpangan baku sebesar 2,18 median 14. Distribusi Frekuensi dapat dilihat pada tabel 4 di bawah ini :

\section{Tabel 4.4. Distribusi Frekuensi Flying}

\begin{tabular}{|c|c|c|c|c|}
\hline \multirow[b]{3}{*}{ No } & \multicolumn{3}{|c|}{ Shoot $(\mathbf{Y})$} & \multirow[b]{3}{*}{$\begin{array}{l}\text { Titik } \\
\text { Tengah }\end{array}$} \\
\hline & \multirow[b]{2}{*}{ Interval Kelas } & \multicolumn{2}{|c|}{ Frekuensi } & \\
\hline & & Absolut & $\begin{array}{c}\text { Relatif } \\
(\%)\end{array}$ & \\
\hline 1 & $12.58-13.18$ & 6 & $30 \%$ & 12.88 \\
\hline 2 & $13.19-13.79$ & 3 & $15 \%$ & 13.49 \\
\hline 3 & $13.80-14.40$ & 5 & $25 \%$ & 14.10 \\
\hline 4 & $14.41-15.01$ & 1 & $5 \%$ & 14.71 \\
\hline 5 & $15.02-16.58$ & 5 & $25 \%$ & 15.80 \\
\hline & Jumlah & 20 & $100 \%$ & \\
\hline
\end{tabular}

Berdasarkan tabel 4.4 di atas dibandingkan dengan nilai rata-rata, terlihat testee yang berada pada kelas ratarata sebanyak 6 testee (30\%) dan yang berada di bawah kelas rata-rata sebanyak 4 testee (20\%), sedangkan testee yang berada di atas kelas rata-rata sebanyak 10 testee $(50 \%)$.

\section{PENGUJIAN HIPOTESIS}

1. Hubungan Antara Koordinasi Mata Tangan dengan Kemampuan Flying Shoot.

Hubungan antara koordinasi mata tangan $\left(\mathrm{X}_{1}\right)$ denganflying shoot $(\mathrm{Y})$ ditunjukan oleh koefisien korelasi ry1 = 0,30. Koefisien korelasi tersebut harus diuji terlebih dahulu mengenai keberartiannya, sebelum digunakan untuk mengambil kesimpulan. Hasil uji koefisien korelasi tersebut dapat dilihat dalam tabel berikut :

\section{Tabel 4.5. Uji Keberartian Koefesien Korelasi $\left(\mathrm{X}^{\mathbf{1}}\right)$ dengan $(\mathrm{Y})$}

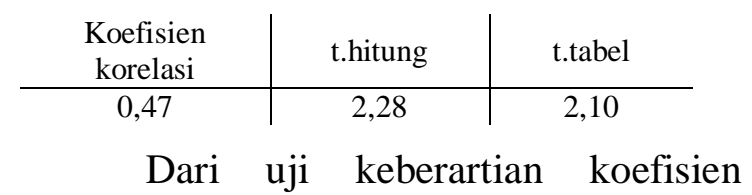
korelasi di atas terlihat bahwa $t_{\text {hitung }}=2,28$ lebih besar dari $t_{\text {tabel }}=2,10$ berarti koefisien korelasi $\mathrm{ryl}=0,30$ adalah signifikan.

\section{Hubungan antara Agility dengan Kemampuan Fliying Shoot}

Hubungan antara Agility $\left(\mathrm{X}_{2}\right)$ dengan kemampuan flying shoot (Y) ditunjukan oleh koefisien korelasi ry2 = 0,47. Hasil uji koefisien korelasi tersebut dapat dilihat dalam tabel berikut :

\section{Tabel 4.6. Uji keberartian Koefisien Korelasi $\left(\mathrm{X}_{2}\right)$ dengan $(\mathrm{Y})$}

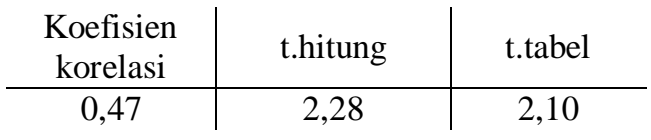

Dari uji keberartian koefisien korelasi di atas terlihat bahwa $t_{\text {.hitung }}=2,28$ lebih besar dari $t_{\text {tabel }}=2,10$ berarti koefisien korelasi ryl $=0,47$ adalah signifikan.

3. Hubungan antara Koordinasi Mata Tangan dan Agility Terhadap Kemampuan Tembakan Melayang (Fling Shoot) pada Atlet Putra Klub Bola Tangan UNJ

Hubungan antara koordinasi mata tangan $\left(\mathrm{X}_{1}\right)$ dan Agility $\left(\mathrm{X}_{2}\right)$ 
dengankemampuan flying shoot (Y) dinyatakan oleh persamaan regresi $\hat{Y}=$ $26,5+0,25 \mathrm{X}_{1}+0,22 \mathrm{X}_{2}$. Sedangkan hubungan antara ketiga variabel tersebut dinyatakan oleh koefisien korelasi ganda Ry1-2 = 0,37. Koefisien korelasi ganda tersebut, harus di uji terlebih dahulu mengenai keberartiannya sebelum digunakan untuk mengambil kesimpulan. Hasil uji koefiesien korelasi ganda tersebut dapat dilihat dalam tabel berikut :

\section{Tabel 4.7. Uji keberartian Koefisien Korelasi Ganda}

\begin{tabular}{c|c|c}
$\begin{array}{c}\text { Koefisien } \\
\text { korelasi }\end{array}$ & F.hitung & F.tabel \\
\hline 0,37 & 2,33 & 2,15
\end{tabular}

Uji keberartian koefisien korelasi di atas terlihat bahwa F.hitung $=2,33$ lebih besar dari F.tabel $=2,15$. Berarti koefisien tersebut Ry1-2 = 0,37 adalah signifikan. Koefisien determinasi $\left(\mathrm{Ry}_{1.2}\right)^{2}=0,14$ hal ini berarti bahwa 14\% kemampuanflying shootditentukan oleh koordinasi mata tangan dan agility.

\section{PEMBAHASAN}

Berdasarkan dari hasil penelitian yang telah dilakukan, maka dapat ditemukan hasil penelitian menunjukkan: pertama, terdapat hubungan yang berarti antara koordinasi mata tangan dengan flying shoot, dengan persamaan garis linier $\hat{\mathrm{Y}}=10+0,30 \mathrm{X} 1$, koefisien korelasi (ry1) $=0,30$ dan koefisien determinasi $\left(\mathrm{ry}^{2}{ }^{2}\right)=$ 0,2209 , yang berarti variabel koordinasi mata tangan memberikan sumbangan dengan kemampuan flying shoot sebesar $22,1 \%$. Kedua, Terdapat hubungan yang berarti antara agility dengan kemampuan flying shoot, dengan persamaan garis linier $\hat{\mathrm{Y}}=10+0,47$ X2., koefisien korelasi (ry2) $=0,47$ dan koefisien determinasi $\left(\mathrm{ry}^{2}{ }^{2}\right)=$ 0,2209 yang berarti variabelagility memberikan sumbangan dengan kemampuan flying shoot sebesar 22,1\%. Ketiga, terdapat hubungan yang berarti antara koordinasi mata tangan dan agility dengan kemampuan flying shoot dengan persamaan garis linier $\hat{\mathrm{Y}}=10+0,25 \mathrm{X}_{1}+$
$0,22 \mathrm{X}_{2}$, koefisien korelasi Ry1-2 $=0,37$ dan koefisien determinasi (Ry1-2) ${ }^{2}=0,14$ yang berarti variabel Koordinasi mata tangan dan Agility memberikan sumbangan dengan kemampuan flying shootsebesar $14 \%$.

Dalam penelitian ini koordinasi mata tangan dan Agility secara bersamasama memberikan kontribusi sebesar 14\% kemampuan flying shoot. Untuk itu disarankan agar peneliti yang lain juga mencari faktor lain yang memberikan kontribusi yang baik dengan teknik kemampuan flying shoot.

\section{PENUTUP}

Kesimpulan. Berdasarkan hasil penelitian yang terdapat pada bab IV, maka penelitian dapat menarik kesimpulan sebagai berikut:

1. Terdapat hubungan yang berarti antara koordiansi mata tangan dengan kemampuan flying shoot pada atlet putra klub bola tangan Universitas Negeri Jakarta.

2. Terdapat hubungan yang berarti antara agility dengan kemampuan flying shoot pada atlet putra klub bola tangan Universitas Negeri Jakarta.

3. Terdapat hubungan yang berarti antara koordinasi mata tangan dan agility dengan kemampuan flying shoot pada atlet putra klub bola tangan Universitas Negeri Jakarta.

Saran.Berdasarkan kesimpulan dan hasil penelitian, maka dapat diajukan saran sebagai berikut:

1. Dalam cabang olahraga permainan seperti cabang olahraga bola tangan, komponen kemampuan fisik salah satunya koordinasi sangat perlu diperhatikan, terutama pada koordinasi mata tangan karena dalam cabang olahraga bola tangan, koordinasi dibutuhkan untuk pergerakan pemain dalam melakukan gerak dapat melihat juga peluang tembak, oleh karena itu 
diharapkan para pelatih memberikan program latihan untuk koordinasi.

2. Selain koordinasi, ada komponen kemampuan fisik lain yang harus diperhatikan oleh pelatih yaitu agility (kelincahan), karena agility dalam cabang olahraga bola tangan juga sangat diperlukan untuk melakukan gerak dalam membongkar pertahanan lawan dan mengbuyarkan konsentrasi lawan sertamencari peluang untuk menembak, oleh karena itu diharapkan para pelatih tidak menganggap remeh kemampuan fisik yang satu ini yaitu aglity (kelincahan) maka pelatih harus memberikan program latihan untuk agility (kelincahan), apabila seorang atlet bola tangan mempunyai kemampuan agility (kelincahan) yang bagus akan mempersulit lawan untuk bertahan dan berkonsentrasi.

3. Dalam permainan bola tangan mempunyai banyak teknik dalam bermain. Diantaranya yaitu teknik menggiring (dribbling) bola, mengoper (passing) bola serta teknik menembak (shooting) yang lain karena didalam cabang olahraga bola tangan mempunyai beberapa teknik menembak bukan hanya flying shoot saja. Maka sebaiknya agar penelitipeneliti yang lain dapat membuat penelitian tentang teknik-teknik yang ada pada cabang olahraga bola tangan.

\section{DAFTAR RUJUKAN}

Agus Mahendra. Bola Tangan Departemen Pendidikan Nasional Direktorat Jendral Pendidikan Dasar Dan Menengah Bagian Proyek Penataran Guru SltpStara D-III, 2000.

Aip Sjarifuddin. Pendidikan Olahraga Kesehatan. Jakarta, 1987.

Abdul Latif, Djumidar Aw. Hubungan Antara Koordinasi Dan Kecepatan dengan Kemampuan Menggiring Bola Basket. Jakarta: FakultasI lmu
Keolahrgaan: Universitas Negeri Jakarta, 2003.

Bompa Tudor O. Theory And Methodology Of Training. Canada : Departemen Of Psical Education York University, 1983.

Broer, Zamicke, dalam Harsono. Coaching Dan Aspek-Aspek Psikologi dalam Coaching. Jakarta : Tambak Kusuma, 1989.

Clanton E.Relta, Mary Phyl Dwight. Team Hand Step To Success. Atlanta : Human Kinetics, 1997.

Djarwanto P.S. Beberapa Uji Statistic Dalam Penelitian, Yogyakarta : Liberty, 1996.

Harsono. Latihan Kondisi Fisik, Jakarta : Pusat Pendidikan Dan Penataran. 1993.

Kirkendall Don, dkk. Pengukuran dan Evaluasi untuk Guru Pendidikan Jasmani Terjemahan oleh Winarno. Jakarta : PPS IKIP Jakarta, 1997.

Lubis Johansyah. Panduan Praktis Penyusunan Program Latihan. Jakarta : Pt Raja Grafindo Persada, 2013.

M. Sajoto. Peningkatan \& Pembinaan Kekuatan Kondisi Fisik Dalam Olahraga. Jakarta : Dahana Prize, 1996.

Nasution. S. Metode Research. Jakarta: Bumi Aksara.

Sugiono. Metode Penelitian Administrasi. Bandung : Alfabeta,1994.

Statistik Untuk Penenlitian. Bandung : Cv.Alfabeta, 2009.

Widiastuti. Tes Dan Pengukuran Olahraga. Jakarta : Pt.Bumi Timur Jaya, 2011.

www.wordpress.Macam-Macam-

Shooting-Dalam-Bolatangan diakses pada tanggal 18 November 2013

www.Seanbase.Wordpress.bolatangan.Com diakses pada tanggal 12 Desember 2013

www.Permainan-Bola-Tangan.Com diakses pada tanggal 12 Desember 2013 
www.Yukes.Wordpress.Bola-Tangan-

Hand-Ball-Games.com diakses pada tanggal 12 Desember 2013. 